\title{
Elongate Twig Ant, Mexican Twig Ant (suggested common names), Pseudomyrmes gracilis (Fabricius) (Insecta: Hymenoptera: Formicidae: Pseudomyrmecinae) $)^{1}$
}

Patricia L. Toth ${ }^{2}$

\section{Introduction}

Pseudomyrmex gracilis (Fabricius), often called the elongate or Mexican twig ant, is a neotropical, arboreal ant best known for its associations with plants and its terrible sting (Wheeler and Wheeler 1956, Ward 1990). This ant belongs to the subfamily Pseudomyrmecinae and is described as a long, solitary, wasp-like ant (Ward 1990, Ferster et al. 2000). It feeds on live insects (especially lepidopteran larvae), fungus spores, and tends aphids for honeydew (Whitcomb et al. 1972, Ferster et al. 2000).

\section{Synonymy}

Pseudomyrma gracilis var. longinoda Enzmann 1945

Pseudomyrma gracilis var. velifera Stitz 1933

Pseudomyrma gracilis var. glabriventris

Santschi 1922
Pseudomyrma gracilis var. guayaquilensis Forel 1907

Pseudomyrma pilosula F. Smith 1877

Pseudomyrma variabilis F. Smith 1877

Pseudomyrma canescens F. Smith 1877

Pseudomyrmex mexicanus Roger

Pseudomyrma mexicana Roger 1863

Pseudomyrma dimidiata Roger 1863

Pseudomyrma sericata F. Smith 1855

Pseudomyrma bicolor Guerin 1844

Formica gracilis Fabricius 1804

(From Ward 1993 and Deyrup 2003)

1. This document is EENY-418 (IN752), one of a series of Featured Creatures from the Entomology and Nematology Department, Florida Cooperative Extension Service, Institute of Food and Agricultural Sciences, University of Florida. Published: September 2007. This document is also available on Featured Creatures Website at http://creatures.ifas.ufl.edu. Please visit the EDIS Website at http://edis.ifas.ufl.edu.

2. Patricia L. Toth, graduate assistant, Entomology and Nematology Department, University of Florida, Gainesville, FL 32611.

The Institute of Food and Agricultural Sciences (IFAS) is an Equal Opportunity Institution authorized to provide research, educational information and other services only to individuals and institutions that function with non-discrimination with respect to race, creed, color, religion, age, disability, sex, sexual orientation, marital status, national origin, political opinions or affiliations. U.S. Department of Agriculture, Cooperative Extension Service, University of Florida, IFAS, Florida A. \& M. University Cooperative Extension Program, and Boards of County Commissioners Cooperating. Larry Arrington, Dean 


\section{Distribution}

Originally from Mexico, $P$. gracilis is found from the southern United States to Argentina and Brazil (Ward 1993). In the U.S., P. gracilis is only found in Texas, Florida, and Hawaii, but could possibly be established in Louisiana. (Whitcomb et al. 1972, Ward 1985, Starr et al. 2004).

Pseudomyrmex gracilis is also found in Jamaica (Ward 1985, 1993).

See the Interactive distribution map for $P$. gracilis at Discover Life.

Pseudomyrmex gracilis was first discovered in Florida at Dade Co. in the 1960s (Whitcomb et al. 1972, Deyrup et al. 1988, Ferster et al. 2000). Currently, $P$. gracilis can be found throughout most of the Florida peninsula and some locations in the panhandle (Johnson 1986, Deyrup et al. 1989, Klotz et al. 1995, Ferster et al. 2000).

\section{Description}

Adult: The adult is best described as a large (8 to $10 \mathrm{~mm}$ ), slender, wasp-like ant (Whitcomb et al. 1972, Ward 1985, 1990, Forster et al. 2000). It has large eyes, a two-segmented petiole, and a well-developed sting (Whitcomb et al. 1972, Ward 1990). Its head is broad and has a twelve-segmented antenna (Ward 1985, 1993, Ferster et al. 2000). Erect hairs cover its body (Ferster et al. 2000).

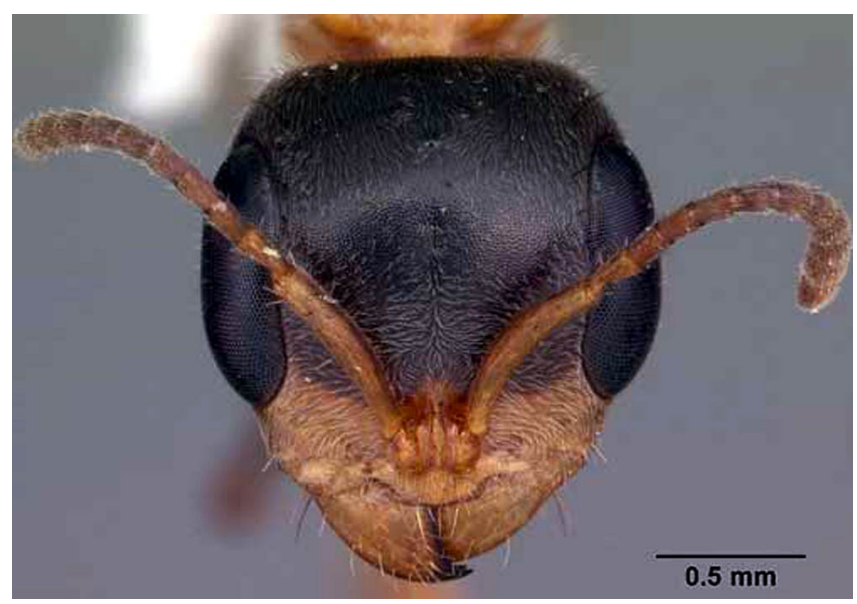

Figure 1. Head of adult elongate twig ant, Pseudomyrmex gracilis (Fabricius), collected in tropical hardwood hammock, Collier Seminole State Park, Collier County, Florida. Credits: April Nobile, California Academy of Sciences. www.antweb.org

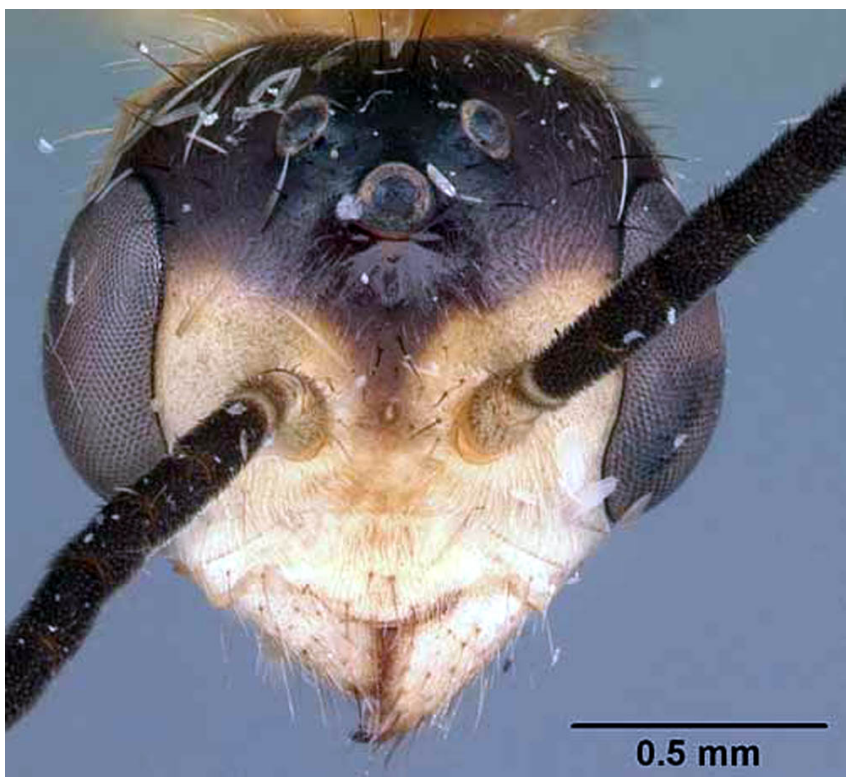

Figure 2. Head of adult elongate twig ant, Pseudomyrmex gracilis (Fabricius), collected in sand pine scrub, Archbold Biological Station, Highlands County, Florida. Credits: April Nobile, California Academy of Sciences. www.antweb.org

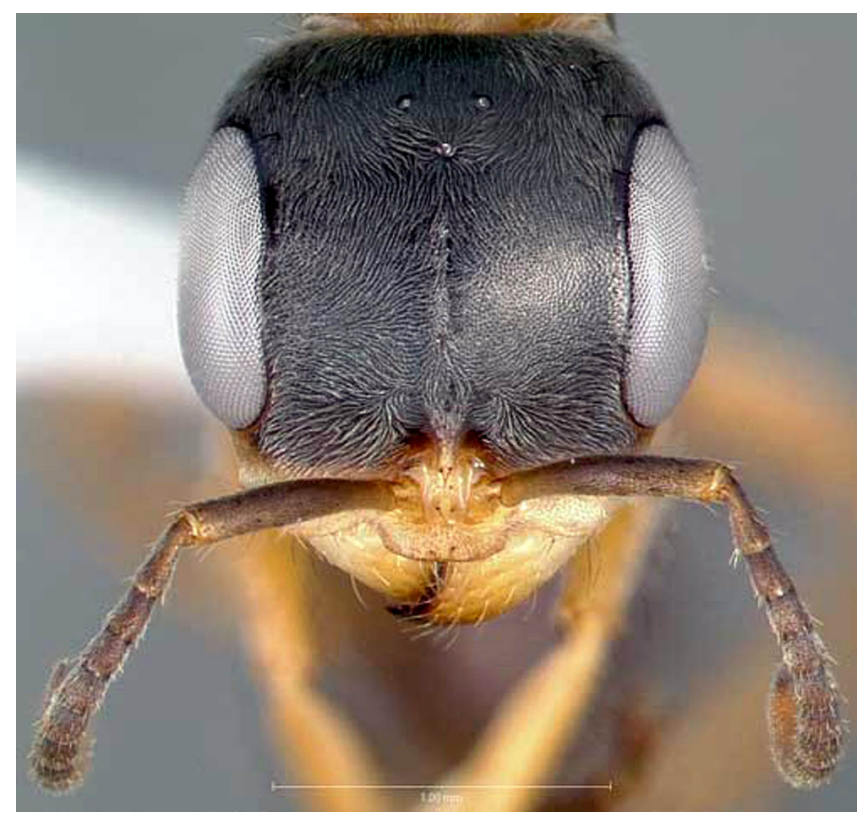

Figure 3. Head of adult elongate twig ant, Pseudomyrmex gracilis (Fabricius), collected on roadside vegetation, in Venezuela. Credits: April Nobile, California Academy of Sciences. www.antweb.org.

The color of $P$. gracilis specimens differs greatly due to large geographical variations (Ward 1985, 1993). The color can range from dark brown-black, to orange-brown, or a mixture of orange and brown [bicolored] (Ward 1985, 1993). Bicolored ants usually have a dark head and abdomen while the thoracic region is light orange in color, but variations 
occur (Whitcomb et al. 1972, Ward 1993, Ferster et al. 2000). The variation found in Florida is mostly described as bicolored with a black head, black abdomen, and an orange middle region. This bright color pattern may serve as a warning to predators, especially vertebrates, of the ant's painful sting (Holldobler and Wilson 1990).

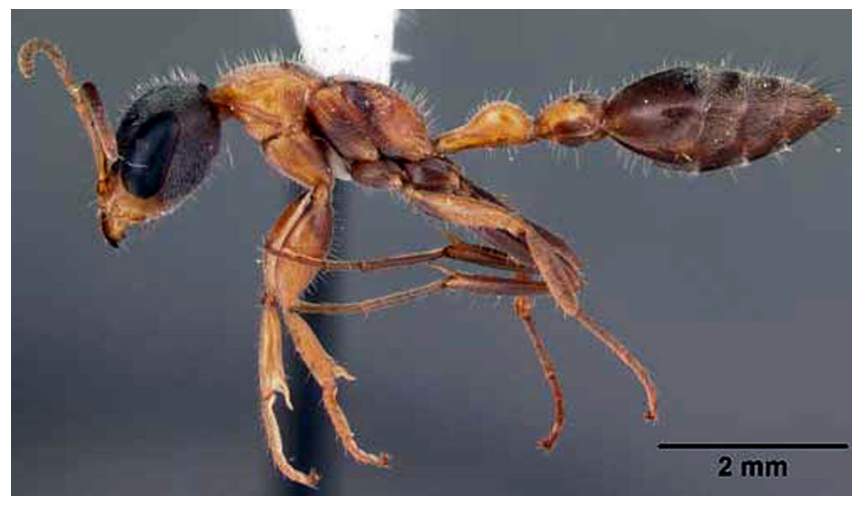

Figure 4. Lateral view of adult elongate twig ant, Pseudomyrmex gracilis (Fabricius), in tropical hardwood hammock, Collier Seminole State Park, Collier County, Florida. Credits: April Nobile, California Academy of Sciences. www.antweb.org

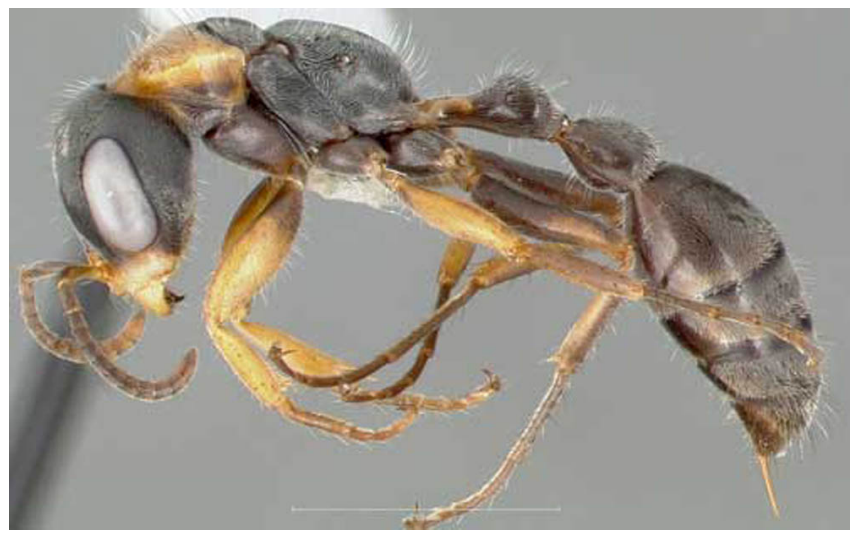

Figure 5. Lateral view of adult elongate twig ant, Pseudomyrmex gracilis (Fabricius), collected on roadside vegetation. in Venezuela. Credits: April Nobile, California Academy of Sciences. www.antweb.org

Larva: A worker larva is long (6 mm), slim, subcylindrical, and covered with short hairs (Wheeler and Wheeler 1956). Like the adult, it is arboreal and can be found inhabiting plant cavities (Wheeler and Wheeler 1956, Holldobler and Wilson 1990). The most distinguishing characteristic is the trophothylax (Wheeler and Bailey 1920, Wheeler and Wheeler 1956). The trophothylax is an enlarged pocket just behind the mouth, but located on the 1st thoracic segment. The larva is fed by a worker adult, which

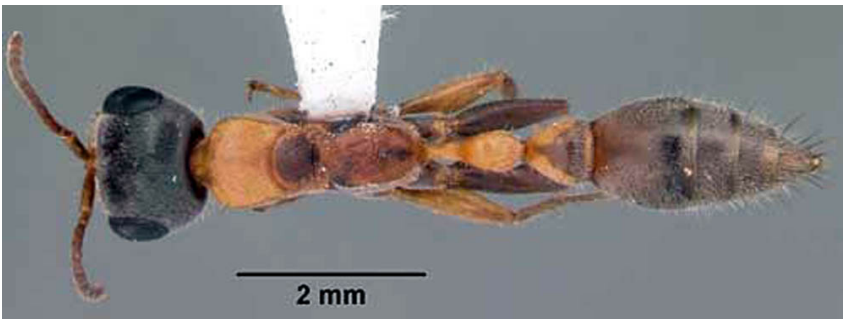

Figure 6. Dorsal view of adult elongate twig ant, Pseudomyrmex gracilis (Fabricius), collected on tropical hardwood hammock, Collier Seminole State Park, Collier County, Florida. Credits: April Nobile, California Academy of Sciences. www.antweb.org.

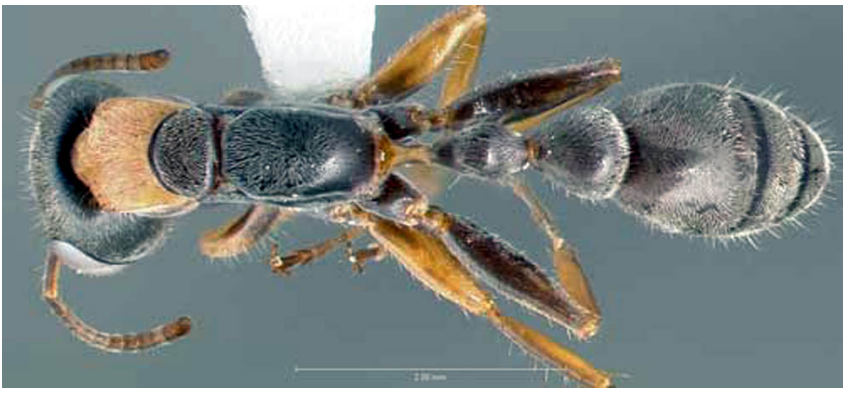

Figure 7. Dorsal view of adult elongate twig ant, Pseudomyrmex gracilis (Fabricius), collected on roadside vegetation. in Venezuela. Credits: April Nobile, California Academy of Sciences. www.antweb.org.

places a firm, dry pellet into the larvae's trophothylax (Wheeler and Wheeler 1956).

\section{Life Cycle}

There is no specific information relating to the colony life cycle of $P$. gracilis, but the following is common to most ant species. Ant species are perennial and colony growth can be achieved through three stages of development: founding, ergonomic, and reproduction (Holldobler and Wilson 1990). During the founding stage, virgin queens leaves the nest to mate with a male reproductive. The queen mates and then begins a new nest by laying eggs and tending the brood. Once the first group of workers develop, the workers take over colony maintenance and the queen's only responsibility is to lay eggs. The colony grows by producing more and more sterile workers; this is the ergonomic stage. Finally, the colony is large enough to produce reproductives (alates) that will disperse generating new colonies, which is the reproduction stage. (Holldobler and Wilson 1990). 


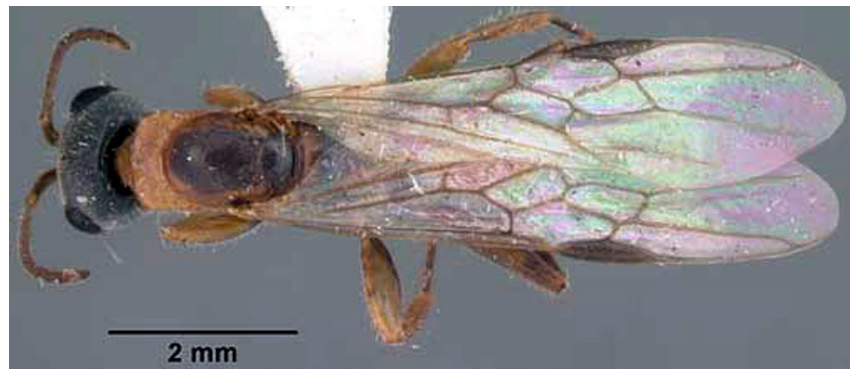

Figure 8. Dorsal view of adult elongate twig ant, Pseudomyrmex gracilis (Fabricius), collected on roadside vegetation. in Venezuela. Credits: April Nobile, California Academy of Sciences. www.antweb.org

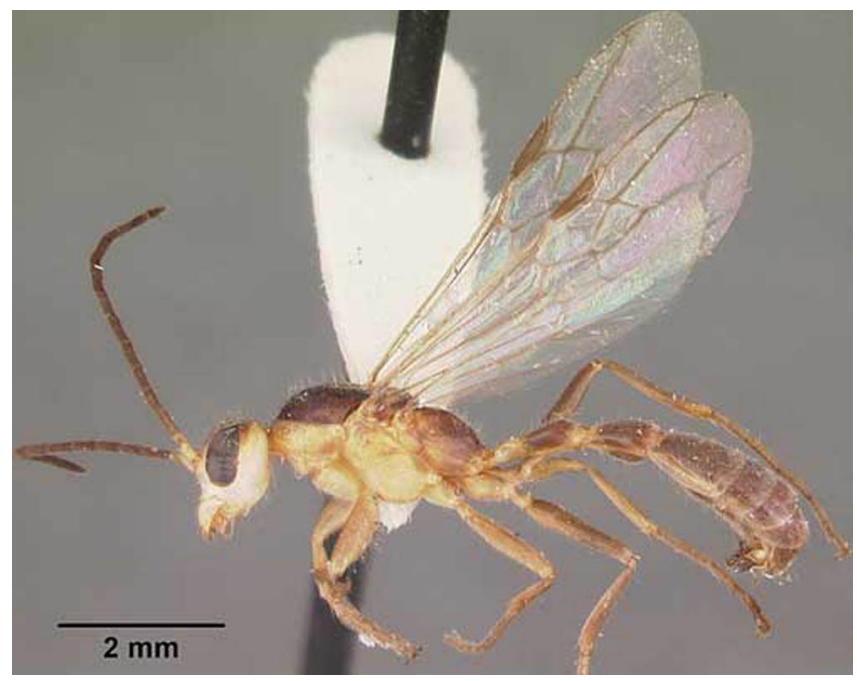

Figure 9. Dorsal view of winged reproductive of adult elongate twig ant, Pseudomyrmex gracilis (Fabricius), collected in sand pine scrub, Archbold Biological Station, Highlands County, Florida. Credits: April Nobile, California Academy of Sciences. www.antweb.org.

\section{Nests}

Nests are small, monogyne (single queen) colonies that can be found in a wide range of habitats including rainforests, mangroves, thorn scrub, secondary growth fields, and hardwood hammocks (Ward 1985, 1993). There is only one small entrance into the nest (Ferster et al. 2000).

There are no known pheromone trails associated with $P$. gracilis to aid nest relocation. Instead, adult workers carry other aged workers, queens, and males to the new nest site. This is done by the worker seizing its nestmate by the petiole or head and then curling the nestmate over the worker's body (Holldobler and Wilson 1990).
Pseudomyrmex gracilis is most likely to be found nesting in naturally occurring hallow cavities such as dead twigs, small branches, or large plant stalks (Wheeler and Wheeler 1956, Whitcomb et al. 1972, Deyrup et al. 1988, Holldobler and Wilson 1990, Ward 1993). This species is able to excavate their own nesting cavity if the material is pliable, but it is not unusual for nests to be found in tunnels made by cerambycids (long-horned beetles) or other insects (Whitcomb et al. 1972, Holldobler and Wilson 1990). However, Pseudomyrmex spp. are best known to be associated with bull horn acacias (Wheeler and Wheeler 1956, Whitcomb et al. 1972, Deyrup et al. 1988, Ward 1993).

\section{Hosts}

Unlike other members of Pseudomyrmecines, $P$. gracilis is not an acacia-specialist, but rather a generalist, nesting in a wide range of different vegetation (Ward 1993). Its nest can be high up in trees, in blades of grass or herbs, and in shoulder high shrubs (Whitcomb et al. 1972, Ward 1985, Ferster et al. 2000). Known nests of $P$. gracilis have been found in exotic ant-acacia trees in Florida such as Acacia cornigera (Wetterer and Wetterer 2003). Nests also have been found in Brazilian peppertree, Schinus terebinthifolius Raddi, that have died due to freezing temperatures (Whitcomb et al. 1972, Cassani 1986).

Pseudomyrmex gracilis will defend its host plant by swarming and stinging intruders (Wheeler and Wheeler 1956).

\section{Damage}

There is little or no ornamental plant or structural damage caused by $P$. gracilis. However, a survey by Klotz et al. (1995) reported $P$. gracilis nesting in wooden doors inside several homes.

\section{Management}

Pseudomyrmex gracilis can have a relatively painful sting, but because they are usually only encountered outside in small numbers, management is not necessary (Ferster et al. 2000). 


\section{Selected References}

Cassani JR. 1986. Arthropods on Brazilian peppertree, Schinus terebinthifolius (Anacardiaceae), in South Florida. The Florida Entomologist 69: 184-196.

Deyrup M. 2003. An updated list of Florida ants (Hymenoptera: Formicidae). The Florida Entomologist 86: 43-48.

Deyrup M, Johnson C, Wheeler GC, Wheeler J. 1989. A preliminary list of the ants of Florida. The Florida Entomologist 72: 91-101.

Deyrup MA, Carlin N, Trager J, Umphrey G. 1988. A review of the ants of the Florida Keys. The Florida Entomologist 71: 163-176.

Ferster B, Deyrup M, Scheffrahn RH. (2000). The pest ants of Florida. http://flrec.ifas.ufl.edu/ entomo/ants/Pest\%20Ants\%20of\%20FL/index.htm (23 June 2007).

Holldobler B, Wilson EO. 1990. The Ants. Harvard University Press. Cambridge, MA. 732 p.

Johnson C. 1986. A north Florida ant fauna (Hymenoptera: Formicidae). Insecta Mundi 1: 243-246.

Klotz JH, Mangold JR, Vail KM, Davis Jr LR, Patterson RS. 1995. A survey of the urban pest ants (Hymenoptera: Formicidae) of peninsular Florida. The Florida Entomologist 78: 109-118.

Starr F, Starr K, Loope L. 2004. New arthropod records from Kaho'olawe. Bishop Museum Occasional Papers 79: 50-54.

Ward PS. 1985. Neartic species of the genus Pseudomyrmex. Questiones Entomological 21: 209-246.

Ward PS. 1990. The ant subfamily Pseudomyrmecinae (Hymenoptera: Formicidae): generic revision and relationship to other formicids. Systematic Entomology 15: 449-489.

Ward PS. 1993. Systematic studies on Pseudomyrmex acacia-ants (Hymenoptera:
Formicidae: Pseudomyrmecinae). Journal of Hymenoptera Research 2: 117-168.

Wetterer JK, Wetterer AL. 2003. Ants (Hymenoptera: Formicidae) on non-native neotropical ant-acacias (Fabales: Fabaceae) in Florida. The Florida Entomologist 86: 460-463.

Wheeler GC, Wheeler J. 1956. The ant larvae of the subfamily Pseudomyrmecinae (Hymenoptera: Formicidae). Annals of the Entomological Society of America 49: 374-398.

Wheeler WM, Bailey IW. 1920. The feeding habits of pseudomyrmine and other ants. Transactions of the American Philosophical Society 22: 235-279.

Whitcomb WH, Denmark HA, Buren WF, Carroll JF. 1972. Habits and present distribution in Florida of the exotic ant, Pseudomyrmex mexicanus (Hymenoptera: Formicidae). The Florida Entomologist 55: 31-34. 